\title{
Community assessment: Historic Main Street Newmarket
}

\begin{abstract}
Adrian Cammaert
Newmarket's Main Street South area has been the focus of numerous large scale revitalization efforts since the early 2000's. The goal of this Assessment is to critically examine Newmarket's Main Street South area from both economic development and urban design perspectives, and provide strategic recommendations which will define the management and maintenance that is required to increase the economic competitiveness of the area. The recommendations include focusing on cycling tourism as a key point of differentiation.
\end{abstract}

Keywords: Newmarket, Ontario, Canada, downtown, heritage, Historic Conservation District, tourism, cycling tourism

\section{Introduction}

Newmarket's Main Street South area has been the focus of numerous large scale revitalization efforts since the early 2000's. To the everyday resident or visitor, these efforts have translated into a much more enjoyable place in which to live and visit. However, to ensure the continued success of this historic area, constant management and maintenance is required.

The goal of this Assessment is to critically examine Newmarket's Main Street South area from both economic development and urban design perspectives, and provide strategic recommendations which will define the management and maintenance that is required to increase the economic competitiveness of the area. For this assessment, the perspective of the first-time visitor will be taken.

\section{Economic importance of tourism}

Tourism is a $\$ 22.1$ billion industry in Ontario; that is larger than all other industries combined, aside from the construction industry (Sorbara, 2009). With such a significant market force involved, it would be unwise to develop an economic development strategy for a place that did not include this element.

In Canada, tourists are traditionally defined as visitors to a place who "travel at least $80 \mathrm{~km}$ one way...or stay overnight" (King, 2015). Newmarket's tourism market is found in other parts of the Greater Toronto Area (GTA), home to over 6 million people, which is almost entirely within $80 \mathrm{~km}$ from Newmarket and would therefore not meet the traditional definition of a tourist.

However, the United Nations (2010) defines a visitor as a person who travels outside of their usual day-to-day environment; they may be subcategorized as a same-day visitor (or excursionist) if they do not stay in the destination overnight. As such, the average Newmarket 
visitor can be classified as a same day visitor. Seventy percent (70\%) of York Region's tourists are same-day visitors and this segment is the strongest segment of Ontario's tourism market, representing approximately $75 \%$ of all trips (York Region, 2007). Newmarket is ideally situated for this tourism segment, and it will play a leading role in the future economic success of the Town's Historic Main Street area.

Caution must be used when introducing tourism as an economic generator for a community because it creates the opportunity for conflict between local residents and visitors. The needs of residents must be balanced with the needs of the visitor. When such a balance is not achieved, the over-commodification of an area can result. In a process known as the model of creative destruction, the needs of the tourist overtake the needs of residents and the authenticity of an area begins to degrade (Mitchell, Atkinson, \& Clark, 2001). Thankfully, visitors are skeptical of places that feel contrived, vastly preferring authentic, functional places (Brooks, 2010). When a place becomes over-commodified, it begins to feel as though its primary purpose for being is to serve the needs of the visitor over the resident, and the final tourism product becomes compromised. A balance must be found where tourism is maximized to the extent that the local economy benefits, but not overly-maximized to the extent that visitors' needs supersede residents' needs.

\section{Differentiating a Community}

From an urban design standpoint, the best places for visitors are the exact places that are best for residents, as they succeed through five main areas: (1) they exhibit a diversity of uses, (2) they host higher densities, (3) they are transit oriented or at least transit supported, (4) they are interestingly designed, and (5) they are comprised of multiple destinations. In short, these are places that encourage people to stay and amble.

However, even the best-designed area is still providing only the basic requirement for a great destination. Destinations must have a clearly identifiable element that can be used to set it apart from other areas. Identifying such an element, or point of differentiation (Borovilos, 2015), is crucial for the overall economic success of a place in general, but even more so for a specific area within a municipality like a downtown or main street area. The problem is, "at 50,000 feet, most of these areas look roughly the same" (Borovilos, 2015). The challenge is how to make a particular area stand out or appear advantageous over competing areas.

In developing this point of differentiation, many municipalities defer to non-specific positive themes that it may have, such as a high quality of life, educated work force, or even generic themes and phrases such as "something for everyone," or "live, work and play". Although they may be true, these themes and phrases are tremendously overused and therefore fail to have their desired effect (Brooks, 2010). Similarly, there is an over-reliance on cultural heritage in many existing marketing schemes (Brooks, 2010) as most towns have historic centres (albeit some more well-maintained and managed than others) and therefore this alone is not adequate to 
utilize as an economic development driver. It is essential that a specific, unique attribute be found and developed for each municipality or area; the more specific the better.

To some extent, Newmarket's current marketing efforts include these generic themes and standard cultural heritage. Current tourism marketing materials cite the weekly Farmers Market and other cultural events as attractions, suggest visitors take "a stroll down historic Main Street" and "keep active on our extensive network of trails". However there is nothing specific or unique to the Town of Newmarket in general, or the historic Main Street area in particular. This practice in Newmarket is unnecessary as the Town, and in particular the historic Main Street area, has existing unique attributes that can be further developed to the betterment of the local economy.

\section{Assessment Area}

The area for this assessment is bounded by Water Street and D'Arcy Street in the south, Davis Drive in the north, the railway tracks in the east and Church Street and Niagara Street in the west. Main Street South runs north/south through the extent of this area and is the Town's historic core. This assessment area will hereafter be referred to as the "Historic Main Street area".

\section{Figure 1 Map of the Main Street area of Newmarket}

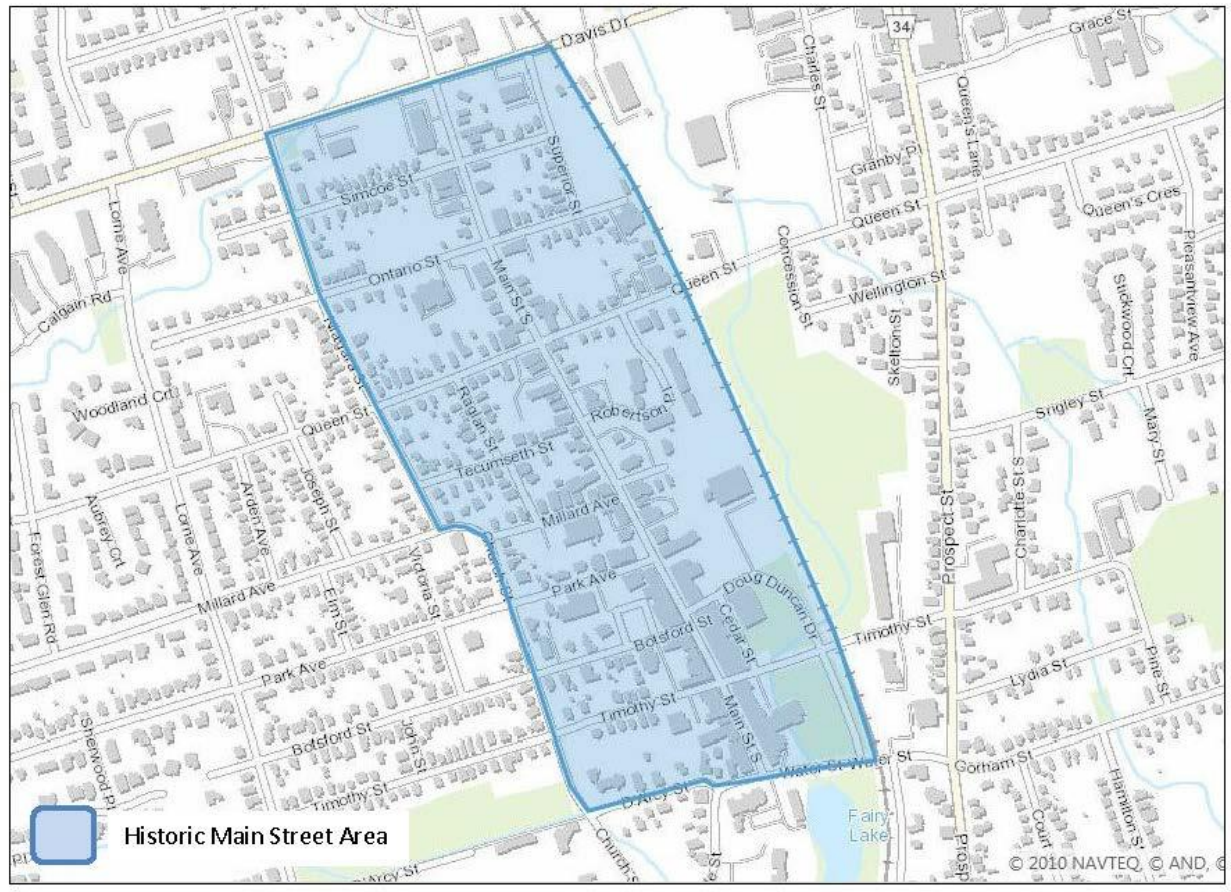

Source: York Region GIS, 2015 


\section{Existing Context}

\section{Unique Situation}

Newmarket's Main Street South is a traditional "main street" urban form. It began as a functional small town Ontario Main Street but has survived into the present context as a vibrant centre. This is an impressive achievement given that many Ontario main streets struggle to remain relevant.

Aside from the commercial core located along Main Street South, the area is also comprised of a historic residential area which provides a 'built-in' market for the commercial area.

It is important to note that the economic success of main streets must be actively managed. Most main streets today have transitioned from "subsistence downtowns", meaning that they do not have a functional economic purpose for existing anymore and therefore their success must be actively managed (Cammaert, 2015).

Figure 2 Main Street South in 1985 (left) and in 2015 after streetscape and building improvements (right)
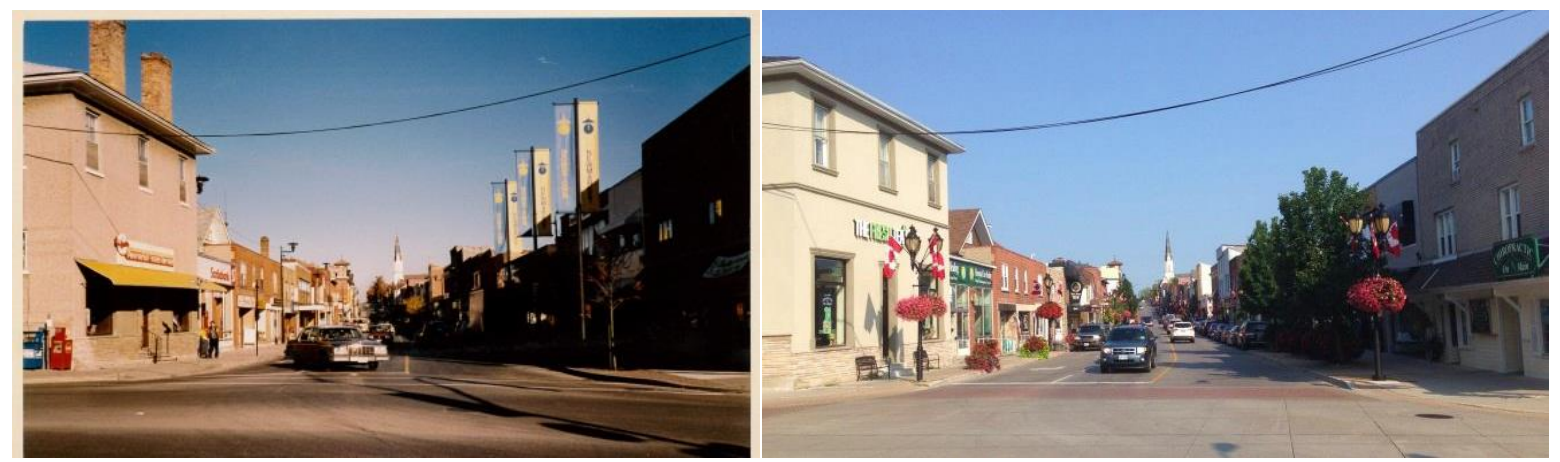

Sources: Town of Newmarket (left), Adrian Cammaert (right)

Previous Revitalization Initiatives

Significant revitalization initiatives have occurred in the Historic Main Street area since the early 2000's, specifically:

- Main Street South road and streetscape improvements (2003);

- The creation of Riverwalk Commons, a public open space (urban park) which includes a splash pad water feature, skating rink and performance stage (2011);

- Redeveloped Community Centre which hosts indoor community event and meeting space (2011);

- Redevelopment of the Old Town Hall into a performance theatre and arts centre (2015); 
- The creation of a Historic Conservation District ${ }^{1}$ under Part V of the Ontario Heritage Act for Main Street South; \&

- The construction of a York Region Transit VIVA bus Rapidway along Davis Drive, abutting the northern extent of the Assessment Area (anticipated completion in late 2015).

\section{Community Improvement Plan}

The private sector is also playing a role in the revitalization of the area. In 2003, Town Council adopted a Community Improvement Plan (CIP), which, under Section 28 of the Planning Act, includes proposals to create an effective implementation vehicle, changes to land use regulations, and capital improvements, as well as a range of financial tools and other incentives for property owners and residents. This Plan led to the creation of a Financial Incentives Program within the CIP area which allows private landowners to apply for financial support, through grants and nointerest loans, to assist with property renovations and improvements. This program has been quite successful, with $\$ 1.6$ million in grants and $\$ 100,000$ in interest-free loans being issued between 2010 and 2014. The CIP has had the effect of increasing property values significantly throughout the area.

\section{Evidence of Success}

The most common method of measuring economic development impacts is by analyzing the total number of new businesses that opened over a set time period (Carr, 2015). It is estimated that 19 new businesses have opened in the Historic Main Street area between 2009 and 2013

(urbanMetrics, 2013). Local business owners indicate that they decided to open their businesses in the area because they are attracted to the overall character of the area, describing Main Street South as "charming", whereas others noted a more economic reason for locating in the area, citing that the area is now where "people want to be" (field inquiries, 2015). These 19 new business openings indicate that the previous revitalization initiatives are having their desired effect of improving the social and economic vitality of the area, and will likely cause a compounded interest in the area moving forward.

\section{Strengths Observed}

One of the Historic Main Street area's greatest strengths is its location. As part of the GTA, Newmarket is part of, and accessible to the largest concentration of people in the country. The Toronto Census Metropolitan Area is home to over 6 million people (Statistics Canada, 2015). Newmarket is well connected to other GTA municipalities, including downtown Toronto by two 400-series highways (directly by Highway 404 and indirectly by Highway 400) and by the GO

\footnotetext{
${ }^{1}$ Historic Conservation Districts are areas whose cultural heritage value contributes to a sense of place extending beyond their individual buildings, structures and landscapes.
} 
rail system. This accessible population base is the potential tourism market for the Historic Main Street area.

The Historic Main Street area's first impression is another advantage. This attribute can be difficult to quantify due to its subjectivity, but the area's visual attributes such as its strong $19^{\text {th }}$ Century building stock, well-maintained streetscape, and attractive businesses, result in a very positive first impression for a visitor. The 2014 approval of a Heritage Conservation District for Main Street South further verifies this impression as it relates to the physical condition and abundance of the area's historic building stock.

It is also apparent that the Historic Main Street area hosts many municipal community assets, including the Old Town Hall, Riverwalk Commons, the Elman Campbell Museum, a regional trail network, and a recently expanded Community Centre. The presence of these assets signifies to the visitor that the area still plays a functional, central role with in the Town, which further bolsters the area's vitality.

The Historic Main Street area is also well served by public transportation. The Newmarket GO Train Station is located to the northeast of the area along Davis Drive. In addition, a York Region Transit VIVA bus Rapidway is being constructed along Davis Drive, abutting the northern extent of the assessment area. This new transportation infrastructure will further increase exposure and introduce more people into the Historic Main Street area.

The unique Main Street situation, off Yonge Street, is also an obvious unique attribute. Like other GTA municipalities such as Toronto, Richmond Hill and Aurora, Newmarket is located along Yonge Street. However unlike these other municipalities, Newmarket's commercial core was not established along Yonge Street. Newmarket began as a mill town, and therefore its founders established the Town's first buildings, and ultimately its commercial Main Street, in proximity to what is today known as the East Holland River, approximately $2 \mathrm{~km}$ east of Yonge Street. This point of distinction has resulted in a significant community/urban design benefit for the Town, allowing its urban core to be located in a more tranquil setting, on narrower streets, with human-scaled buildings. While other Yonge Street municipalities struggle with how to readapt their Yonge Street cores to be more pedestrian-friendly, Newmarket was gifted one by its founders.

The Historic Main Street area also hosts natural attributes that are noticeable by a visitor. The southern terminus of this area is bounded by the Wesley Brooks Memorial Conservation Area, informally known as Fairy Lake, which is a large green space with recreation trails centred on a lake with waterfall. This greenspace acts as a draw for users from other areas in Newmarket as well as other areas of the larger region. Secondly, the East Holland River runs from the falls at the Wesley Brooks Memorial Conservation Area, northward just east of the commercial buildings along Main Street South, creating opportunities for public gathering spaces and the preservation of unique views and vistas. At a larger scale, Newmarket's environs host numerous 
conservation areas and agricultural lands associated with the Oak Ridges Moraine and Greenbelt lands, including the renowned Holland Marsh.

The Historic Main Street area currently hosts a large number of events, including a weekly Farmers Market, Car Shows, Canada Day Festival, Garlic Festival, Jazz+ Festival, Candlelight Parade/Tree Lighting ceremony, Santa Claus Parade, Pumpkin Parade and Winterfest. These events are held at Riverwalk Commons and the Wesley Brooks Memorial Conservation Area, as well as along Main Street South itself. These events bring the community together and further reinforce the role of the area as the Town's cultural centre.

These strengths all have the capacity to positively impact The Historic Main Street area's local economy, but only if they are properly managed and maximized.

\section{Challenges Observed}

A desktop analysis was unable to determine if a marketing plan for the Historic Main Street area exists. Tourism-focused marketing exists for York Region as part of the "Central Counties" (RTO6) and includes limited information on Newmarket in general, however, there doesn't appear to be a co-ordinated Newmarket-led tourism plan.

The desktop analysis was able, however, to determine that the Historic Main Street area lacks cohesive branding. Different language is used to refer to the area in current branding, including "Downtown Newmarket", "Main Street Newmarket" and "Historic Main Street Newmarket". This inconsistency is most noticeable between the advertising and marketing material that exists to promote the area and the vehicular directional signage (discussed below). In addition, current marketing for the area is primarily focused on second tier radio (seasonally) and local newspaper publications, with a limited social media presence.

Although the area boasts numerous positive attributes, none of the marketing materials identify a point of differentiation that would elevate the area as a whole in terms of being a recognizable destination for visitors. As noted, it is imperative that such a specific element be defined.

In the field, it was observed that there is a lack of vehicular directional signage from Highway 404. Although "Historic Main Street Newmarket" is well identified along Highway 404 via Tourism-Oriented Directional Signage (TODS), with approximately 57,500 vehicles passing the "Historic Main Street Newmarket" TODS every day (Ontario Ministry of Transportation, 2010), there is a disconnect between Highway 404 and the Historic Main Street area. A series of small blue directional signs exist in some areas, whereas in others, larger white directional signs exist (see Figure 3). In some instances, these different signs are located in the same site, causing confusion for the visitor. Both the small blue signs and the larger white signs are not overly perceptible, have limited visual appeal, and in many instances are in various states of disrepair. 
Figure 3 Existing vehicular signage

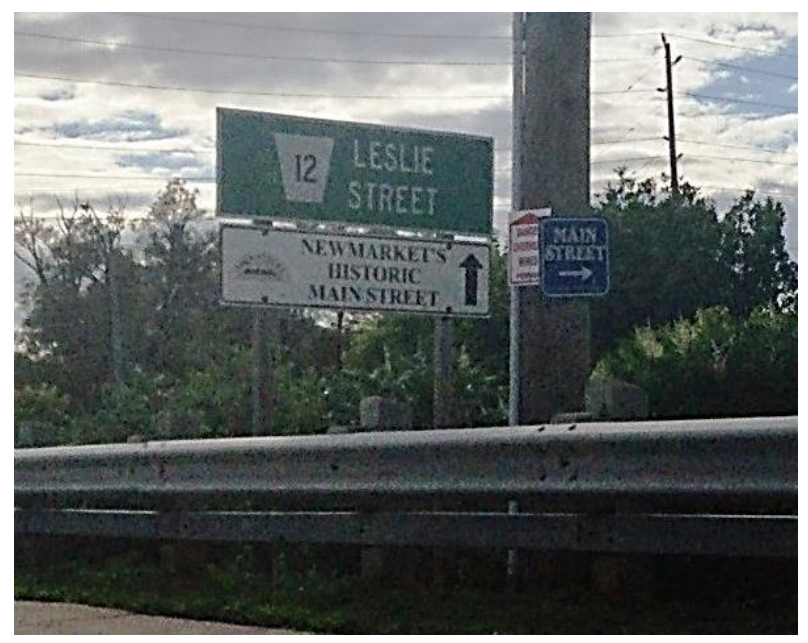

Source: Adrian Cammaert

Similarly, although a Heritage Conservation District was approved for the area in 2014, no vehicular gateway signage exists to exhibit this achievement.

Although parking is often cited as a problem for many main street destinations, in the case of Newmarket's Main Street area, this seems to be an issue of perception or access rather than reality. Approximately 615 parking spaces currently exist, spread out across the Main Street area. It was found that this parking supply is sufficient to meet current demands, however there are imbalances across the lots, which creates the perception that there is not an adequate number of available spaces (BA Group, 2015). Generally, it is good practice not to have parking too close to destination in order to allow for pedestrians to walk to their destinations from their parked vehicles, thereby creating spending opportunities along the way.

There is also a noticeable lack of pedestrian wayfinding signage/information throughout the Historic Main Street area. As noted, the area hosts many community assets such as the Old Town Hall, Riverwalk Commons, the Elman Campbell Museum, a regional trail network and a Community Centre. Residents likely know where these facilities are located, however visitors likely do not. This type of signage does more than simply advise where these facilities are located; it promotes the fact that these places exist (which is especially important for visitors) and can be used to reinforce the defined brand.

Opportunities exist to enhance the pedestrian experience. While the overall streetscape is welcoming, many individual businesses lack enhanced visual appeal, which is not just an aesthetic issue. It is estimated that $70 \%$ of first-time sales at restaurants, retail shops, lodging facilities, and attractions can come from curb appeal, or places that 'look like a nice place to eat (Brooks, 2010). In addition, at the sidewalk level, it is difficult to locate specific stores due to the prevalence of one-dimensional private signage. The use of blade signage (see Figure 4) can enhance the pedestrian experience by assisting shoppers in locating certain stores and contributes 
to the walkability of a place. Further, there are currently limited seating areas (and where they do exist, seating arrangements are awkward).

Figure 4: Visual comparis on of one dimensional signage (left) to blade signage (right)
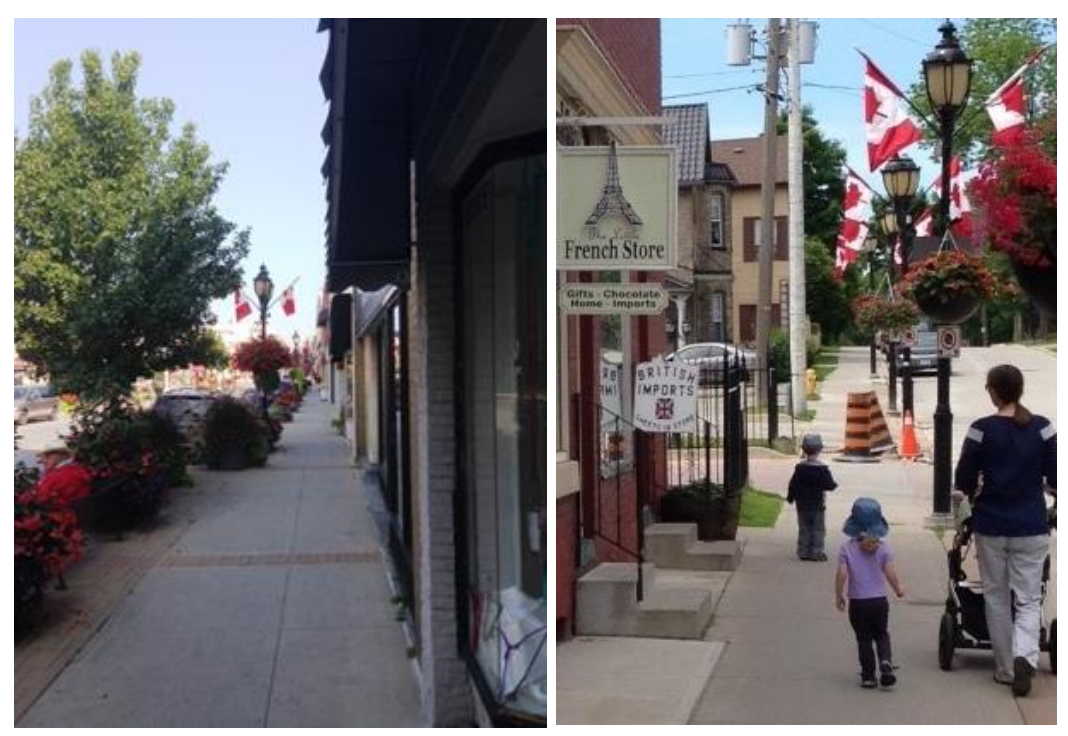

Source: Adrian Cammaert

Although there are a limited number of "bricks and mortar" outdoor eating options as of 2015, the Town has addressed this issue through a pilot program that allows the opportunity for local eating establishments to construct temporary patios over on-street parking spaces. It was observed that the patios are well used and street vitality has increased.

There is a shortage of non-food retail uses within the Historic Main Street area. Main Street South, extending from Davis Drive in the north to Water Street in the south, is the commercial spine of the Historic Main Street area. This street is currently comprised of approximately $22 \%$ non-food store retail uses ${ }^{2}$, less than the ideal target of $30 \%$ for Ontario's main street context of 30\% (M. Ward of Malone Given Parsons, personal communication, 2014). Instead, there is an overabundance of service-employment uses, such as legal, insurance and financial services offices occupying street-level storefronts along Main Street. Since people are drawn to places which offer a range of retail uses, which translate into a boutique shopping experience where unique items can be found, it is extremely beneficial in these instances to have a two storey building stock which is able to accommodate both uses.

It is also noted that the Historic Main Street area lacks a grocery store. Although neighbourhood grocery stores may not be integral from the perspective of a visitor, they are key components of complete communities and are vitally important for local residents. By their nature, they are located in walkable areas and therefore provide local food options without the need for utilizing

\footnotetext{
${ }^{2}$ The Downtown Action Plan (urbanMetrics Inc., 2013) found that there is $56,500 \mathrm{sq} f \mathrm{ft}$ of non -food store retail space, out of a total 261,300 sq feet of retail space.
} 
personal vehicles. However they also provide places where residents can interact with each other at an informal level. A market opportunity exists for a local grocery store in the Historic Main Street area, as it boasts a healthy built-in market of local residents. The population threshold for a grocery store is 1,348 (Friyia, 2015), which is among the lowest of all the types of small businesses. The total residential population within $1 \mathrm{~km}$ of the Main Street South commercial core is 7,194 (urbanMetrics, 2013), making a grocery store easily supportable for this area.

It is further noted that there are inconsistent store hours for commercial businesses within the Historic Main Street area. It appears that the majority of these businesses maintain traditional weekday, daytime business hours. This is problematic because approximately $70 \%$ of all consumer retail spending (in brick \& mortar stores) takes place after 6:00pm, and "shop local" programs only work if stores are open during convenient hours, meaning after work hours or even after dinner hours (Brooks, 2010). In addition, many businesses along Main Street South are closed during premium retail times, such as summer weekends and evenings. This is a revenue loss for individual business owners, but it also has a greater negative impact by removing vitality from the street at a critical time when the highest levels of visitors and pedestrian traffic are present.

From a visitor's perspective, there are three main destinations within (and abutting) the Historic Main Street area: Main Street South, Riverwalk Commons, and the Wesley Brooks Memorial Conservation Area. While each destination functions well independently, none of the three would be a significant visitor destination individually. Therefore, pedestrian connections and visual cues between these three destinations are important in order to attract and accommodate a larger number of visitors. The current context is lacking in this regard, as there are inadequate pedestrian connections between these destination areas.

Specifically, the hill located east of Main Street along Timothy Street presents a barrier to accessing Main Street South from the parking areas below the hill (Figure 5). Further exacerbating this problem are the aesthetics of the rear of the buildings on the east side of Main Street South, facing Cedar Street. The Cedar Street streetscape is dominated by an unsightly appearance comprised of inconsistent garbage enclosures and occasional graffiti (Figure 6) ${ }^{3}$. These poor aesthetics create a physiological divide that worsens the physical divide created by the Timothy Street Hill. The effect of this divide is reduced pedestrian flow between the two areas. This results in diminished spending opportunities by people who are either unable or unwilling to traverse up the hill to explore the area more fully. This is especially problematic due to the popularity of events held at the Riverwalk Commons at the bottom of the hill, and the presence of the historic commercial area at the top of the hill.

\footnotetext{
${ }^{3}$ Formerly a rear ally, Cedar Street became a fronting street with the development of the adjacent Riverwalk Commons in 2011 which had the effect of increasing the exposure to the rear of these buildings. Some businesses have improved the rear-facing appearance of their buildings and are even trying to take advantage of the increased prominence of their businesses through rear-access retail.
} 
Figure 5 Timothy Street Hill

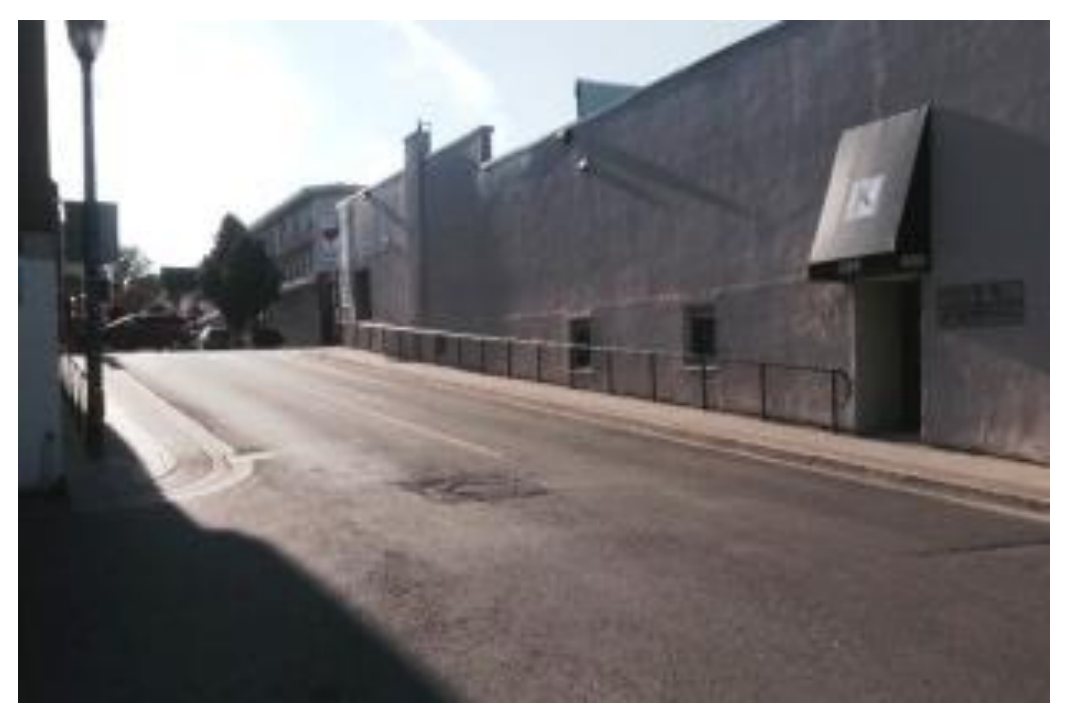

Source: Adrian Cammaert

Figure 6 Cedar Street

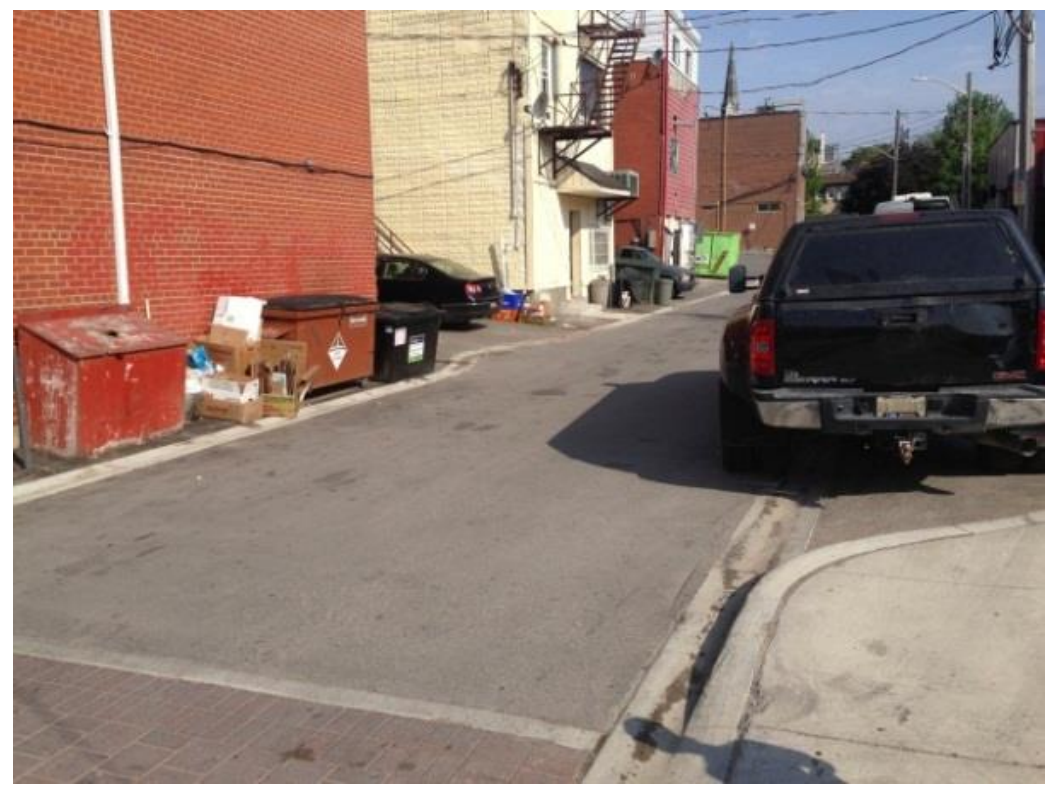

Source: Adrian Cammaert

Similarly, pedestrian flow can also be improved between Riverwalk Commons and the Wesley Brooks Memorial Conservation Area, which is separated by Water Street. This portion of Water Street, near Doug Duncan Drive, is comprised of a right-of-way which accommodates 5 lanes of vehicular traffic (including turning lanes). Currently, in order to cross Water Street, pedestrians utilize a crossing area marked by inlaid bricks. Vehicular traffic along this road is significant and pedestrians may feel unsafe crossing in this location. 
Programming presents an image of an area and can be used to attract pre-determined types of visitors. Programming should be balanced across the seasons and include a premium, signature event component which is centred on the identified point of differentiation. Although the Historic Main Street area currently hosts a large number of events, most of these are communitybased and would be unlikely to draw significant numbers of visitors into the area from beyond the local area. In addition, the majority of these programs are focused on the non-winter months, leaving December to April under-programmed. Finally, without an identified point of differentiation, it is not possible to determine if any of the existing programming is centred on an identified point of differentiation.

\section{Strategic Recommendations}

A series of strategic recommendations have been proposed, corresponding with each challenge observed, as outlined in the previous section. It is recommended that the Town, in conjunction with appropriate partners such as the Main Street Business Association (BIA), begin to undertake these recommendations.

\section{Marketing}

- It is recommended that a detailed marketing plan be created which focuses on the area's main market area: downtown Toronto. Newmarket is fortunate enough to be located within close proximity to the largest market area in the country and efforts should be made to capitalize on this advantage. Special attention should be paid to same-day visitors in line with the identified point of differentiation (see Point of differentiation section below).

- It is important to market three separate destinations-Wesley Brooks Memorial Conservation Area/Fairy Lake, Main Street South and Riverwalk Commons-as one, larger destination (a Triangle Destination).

- New marketing efforts should include significant resources allocated to social media.

\section{Cohesive branding}

- It is recommended that cohesive branding for the Historic Main Street area be developed. Such branding should include a logo for the area as well as sympathetic colours and imagery that can be used in marketing material and vehicular/pedestrian directional signage.

- When developing such branding, a consistent name for the area should be used. The term "downtown" should be avoided as it may cause misinterpretation with downtown Toronto. In an effort to recognize the heritage aspect of the area, while avoiding the use of the term "downtown", the moniker "Historic Main Street Newmarket" is recommended. 


\section{Point of differentiation}

- It is recommended that cycle tourism be the Historic Main Street area's point of differentiation. This is a niche-tourism area that is becoming increasingly popular, and is comprised largely of well-educated, financially secure people who are more likely than other tourists to spend money in an area (Burns, Dudzik, Kola, \& McCulloch, 2014). In addition, Toronto hosts a significant proportion of the cycle tourist market (Burns, Dudzik, Kola, \& McCulloch, 2014). Therefore, cycle tourism has the potential to positively affect the economy. It is a strategy that has worked well in other communities, such as "Bike Town" Devon, AB (Roger Brooks International, 2015).

The region's main off-road cycling route, the Tom Taylor Trail (part of the Nokiidaa Trail System), bisects the Historic Main Street area. This trail system converges with a new trail system, the Greenbelt Route, which was completed in 2015. The future Lake-to-Lake cycling route will connect Lake Simcoe in the north to Lake Ontario in the south, and will utilize sections of the Tom Taylor Trail/Nokiidaa Trail System. This will serve to bring in additional cycle tourists and add to the strength of this point of differentiation. Finally, the Newmarket area already hosts popular rural cycling routes through neighbouring Whitchurch-Stouffville and East Gwillimbury. The presence of this cycling infrastructure and culture establishes a strong basis for this identified point of differentiation.

- It is recommended that an annual, signature cycling event be developed consistent with this point of differentiation (see Programming section below).

- It is recommended that a bicycle rental facility (public or private) be established along or within close proximity to the existing trail system.

- To direct cyclists to the area, it is further recommended that "Historic Main Street Newmarket" directional signage be installed at key locations along the Tom Taylor Trail, including the convergence of this trail system with the Greenbelt Route.

- It is finally recommended that a specific marketing campaign be developed, focused on the same-day cycling visitor from Toronto. Websites, social media, and printed cycling maps should be utilized as marketing mediums, separate but complimentary to those prepared for the Historic Main Street area on a more general basis (see Marketing section above).

\section{Vehicular directional signage}

- It is recommended that the existing blue and white signage be replaced with consistent, aesthetically pleasing, highly visual vehicular directional signage, 
directing vehicles from Highway 404 to the Historic Main Street area. Such signage should be installed along the most direct and scenic route into the area, identified as: west on Mulock Drive, north on Bayview Avenue, and west on Water Street. Such signage should echo the colours and imagery of the identified brand.

Gateway signage

- In an effort to create a sense of place and exhibit the area's Heritage Conservation District status, it is recommended that Heritage Conservation District gateway signage be installed at key locations; specifically on the north side of Water Street between the trail location and the East Holland River bridge to demark and area for people entering the area from the east, and on the south side of Eagle Street behind St. Andrews Presbyterian Church. (It is noted that gateway signage will be installed to demark the northern entrance to the area over Main Street, where it intersects with Davis Drive as part of the Viva Rapidway improvements, and as such no additional gateway signage is recommended in this location.)

Figure 7 Examples of Heritage Conservation District signage in other GTA communities
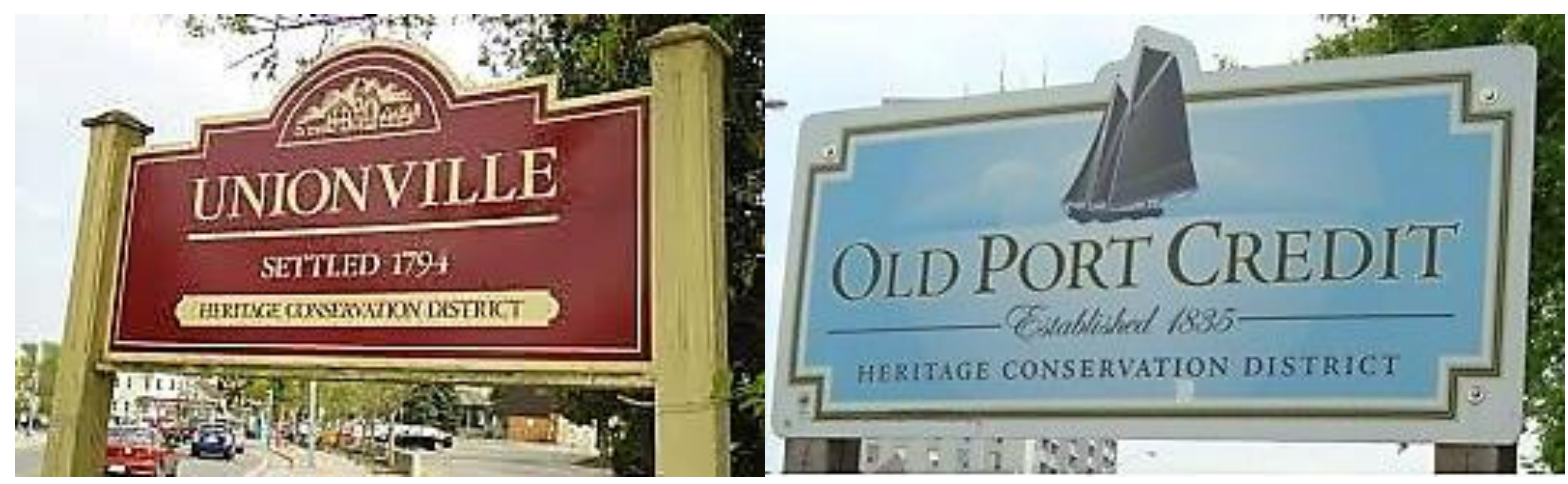

Sources: City of Markham(left), City of Mississauga (right)

Parking

- To combat the perception that there are not enough parking spaces, it is recommended that better signage be installed which clearly identifies the locations of parking lots. This signage should form part of a larger pedestrian wayfinding signage program.

\section{Pedestrian wayfinding signage / information}

- It is recommended that pedestrian wayfinding signage be located throughout the Historic Main Street area, and specifically identify the locations of Riverwalk Commons, Old Town Hall, the Wesley Brooks Memorial Conservation Area and the Elman Campbell Museum. 
- It is also recommended that generic "shops and restaurants $\rightarrow$ " wayfinding signage be installed to increase exposure of the Main Street South commercial area.

- It is further recommended that an information board (see Figure 8) be installed in Riverwalk Commons to provide a map to key points within the area.

Figure 8: Example of an information kiosk directing visitors to key landmarks

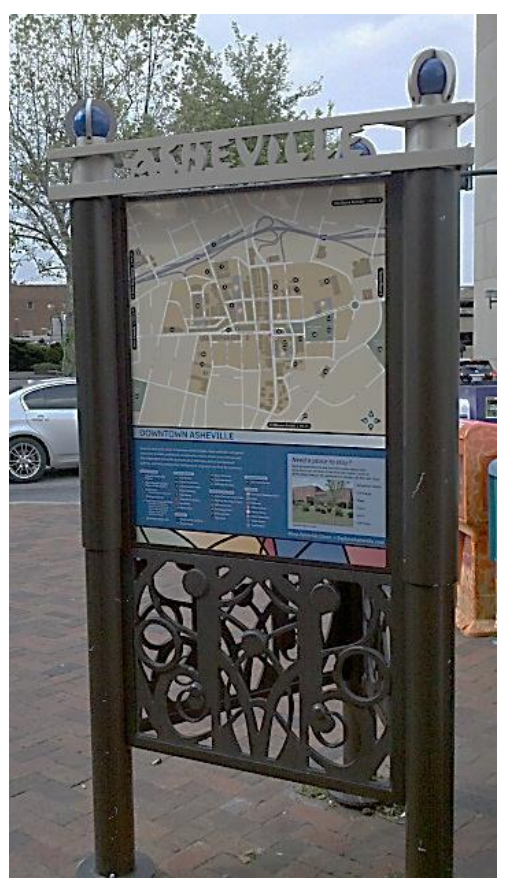

Source: Cluther, S. (2012). Information kiosk. Retrieved from https://seancluther.wordpress.com/2012/05/04/morefrom-asheville-wayfinding/

\section{Enhancement of the pedestrian experience}

- It is recommended that blade signage be permitted and encouraged by merchants. Consistent standards regarding the size, height, material and character should be created.

- It is further recommended that The Town and/or Business Improvement Area, create a pamphlet for distribution among area merchants illustrating best practices regarding window and street displays, seating areas, menu boxes, and blade signage.

- The Town should be commended on the temporary patio initiative and it is recommended that further support be given to this program in the future.

Shortage of non-food (restaurant) retail uses

- It is recommended that efforts be explored to increase the presence of non-food (restaurant) retail uses; this can be achieved in two ways: (i) implementing zoning 
restrictions on non-retail uses on ground floor, and (ii) identifying and encouraging specific retailers from other areas to relocate or expand to the Historic Main Street area.

- It is recommended that the zoning by-law (and official plan if required) be amended to encourage retail uses in commercial properties on Main Street South within the study area. The amendments should restrict service-related office uses to the upper stories, and restrict non-service commercial zoning (which permits a range of retail uses) to ground floors of affected buildings.

- As demand for additional retail space along Main Street increases, planning efforts should be made to extend the urban fabric north from Millard Avenue to Davis Drive. The character along this section of Main Street is currently compromised by large areas of surface parking located in front of buildings and excessively large setbacks. It is recommended that future demand for retail space be accommodated largely through infill intensification and greyfield redevelopment of this area, ensuring that the future built form and massing reflect the historic character of the remainder of Main Street South.

\section{Grocery store presence}

- It is recommended that the Town target small-format grocery stores from outside of the municipality for relocation or expansion within the Historic Main Street area.

\section{Inconsistent store hours}

- It is recommended that the Business Improvement Area focus efforts to achieve more consistent store hours for business within the Historic Main Street area. Having businesses in the area remain open past 6:00pm should be targeted. Business can shift hours to open and close later to maintain the same number of 'open' hours per day. Having consistent 'open' hours during premium retail times, such as summer weekends and evenings, is especially important.

\section{Inadequate pedestrian connections}

- It is recommended that the two alleyways that access Main Street from Riverwalk Commons be illuminated by decorative lighting (see Figure 9) in order to draw nighttime visitors up to Main Street, as well as make the alleyways feel safer.

- It is further recommended that consistent garbage enclosures be installed along Cedar Street to mitigate the negative visual impact and entice people to walk up to Main Street from Riverwalk Commons. 
Figure 9: Creative use of illumination

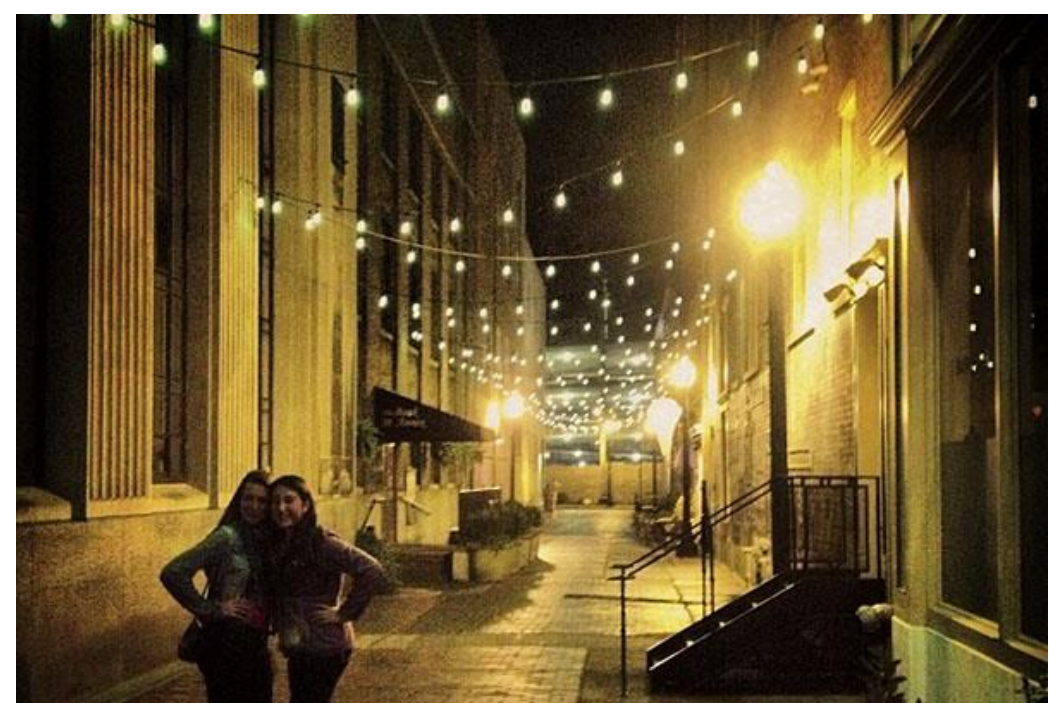

Source: Marraccini, A. (n.d.). String lighting in three pedestrian alleyways. Retrieved from http://www.eastonmainstreet.org/about-downtown/emsi/project-information/

- The use of pedestrian wayfinding signage is recommended to both publicize the presence of the Main Street commercial core, as well as direct them up to Main Street from the numerous, popular events that take place at Riverwalk Commons.

- It is recommended that the Town undertake a study that examines the possibility of implementing traffic calming measures in the area of Water Street and Doug Duncan Drive. Specifically, the use of a raised, signalled pedestrian crossing in unison with a pedestrian refuge island should be considered. Such measures would reinforce the Triangle Destination (see Marketing), may create space to install gateway signage (see Gateway signage), and address potential safety issues for pedestrians crossing Water Street.

\section{Programming}

- In order to more efficiently focus resources and maximize the economic impact, it is recommended that some less popular events, such as the Car Show, Pumpkin Parade and New Year's Levee ${ }^{4}$ be either eliminated or restructured in order to more positively impact the local economy though the attraction of greater numbers of residents and visitors to the area. A new, seasonal programming schedule is suggested:

- New signature spring event - Cycling ride/race. To promote and reinforce cycling as the area's point of differentiation, it is recommended that an annual, large-scale

\footnotetext{
${ }^{4}$ The Downtown Action Plan (urbanMetrics Inc., 2013)
} 
signature cycling ride/race be developed which both begins and finishes in the Main Street area. It is suggested that the route of the cycling ride/race be centred on the well-known routes that exist in the rural areas outside of Newmarket (King, Whitchurch-Stouffville and/or East Gwillimbury). If held as an annual event, the association between the Historic Main Street area and cycling would be reinforced year after year. Starting and finishing the tour within the Historic Main Street area introduces as many people as possible to the area and achieves maximum economic impact for local businesses.

○ Summer event - Canada Day festivities as currently exist.

○ New fall event - A Halloween event that takes advantage of the area's historic building stock and local history. Specific elements could include haunted tours, haunted train ride through the Wesley Brooks Memorial Conservation Area, public ghost story readings, Halloween Harvest Market (last Farmers Market of the season), and/or a costume parade/zombie walk.

○ Updated Christmas event - European Christmas Market. These events are growing in popularity and can positive impacts for local merchants. Such an event could last for three days, and include the existing Candle Light Parade (Friday night), a new European Christmas Market (Friday night to Sunday afternoon), and end with the Santa Claus Parade (Sunday afternoon). These Christmas Markets typically include retail stalls, food stalls and trucks, warm drinks \& temporary fire pits with seating.

○ Updated winter event - Winter Carnival. A signature winter event is important to local merchants as they can draw people to the area during what are typically the most difficult months for business. It is difficult to attract people outside in the winter months, so any idea for such an event must be unique and interactive. It is recommended that the idea of dogsledding to/through the Wesley Brooks Conservation Area be explored for Historic Newmarket. Such an event can be supported by other events like ice sculpture carving competitions, figure skating demonstrations, retail stalls, live entertainment, food stalls and trucks, warm drinks and temporary fire pits with seating.

- Finally, it is recommended that in order to fund new, larger-scale events and programming, the Town place greater emphasis on public-private partnership opportunities.

\section{Competition}

The above recommendations will make Newmarket's Historic Main Street area more competitive. As previously identified, being located within the GTA is a strength for the Historic 
Main Street area. However, this can also be a weakness as many other destinations exist in the GTA that compete with the Historic Main Street area for same-day visitors, including:

- Unionville (City of Markham);

- Port Credit (City of Mississauga);

- Kleinburg (City of Vaughan);

- Port Perry (Scugog Township) ${ }^{5}$;

- Orangeville 6

These places all currently market their "heritage area" attributes and are located within the sameday visitor distance from downtown Toronto. These places are competing with each other for tourism market share and are constantly trying to better position themselves from each other.

Places like St. Mary's, Paris, Elora, Barrie, Cobourg and Port Hope also market their downtown and/or heritage areas and may therefore compete for the same tourism market share, however not to the same extent as they are located further from Toronto's core and the associated market.

\section{Conclusion}

Newmarket's Historic Main Street area has experienced tremendous revitalization over the past 15 years to the benefit of local residents and tourists alike. This assessment critically examined the experience and identifies the areas main strengths as well as its challenges. A series of strategic recommendations were provided to further enhance the visitor and resident experience. As the recommendations are implemented, the Historic Main Street area will gain increasing prominence as a destination.

\section{Author biography}

Adrian Cammaert is a Registered Professional Planner (RPP), a full Member of the Canadian Institute of Planners (MCIP), and fully accredited by the Congress for the New Urbanism (CNU). Adrian has been a practicing Planner in both the public and private sectors in Ontario for the past 10 years. Adrian is also the founder of the Ontario Chapter of the Congress for the New Urbanism, a professional organization which promotes high community \& urban design standards in Ontario, with the goal of enhancing urban life and creating more pedestrianoriented, human-scaled built environments.

\footnotetext{
${ }^{5}$ Not technically in the GTA, but still draws same-day/excursionist visitors from central Toronto.

${ }^{6}$ Not technically in the GTA, but still draws same-day/excursionist visitors from central Toronto.
} 


\section{References}

Borovilos, G. (2015). Business Retention Strategies: Economic Gardening. Presentation.

BA Group (2015). Downtown Newmarket Parking Wayfinding Initial Assessment. Toronto: Author.

Brooks, R. (2010). Destination Development. Presentation.

Burns, H., Dudzik, J., Kola, L., \& McCulloch, M. (2014). Investigating Impacts of Cycle Tourism in Ontario. Ryerson University, Toronto.

Cammaert, A. (2015). Adapting to new economic structure Ontario Planning Journal, 30(5), 23.

Carr, P. (2015). Project Management for Economic Developers. Presentation.

Friyia, D. (2015). Introduction to Financial Analysis for Small Business. Presentation.

King, K. (2015). Tourism Product Development and Marketing. Presentation.

Mitchell, C.J.A., Atkinson, R.G., \& Clark, A. (2001) The creative destruction of Niagara-on-theLake. Canadian Geographer, 45(2), 285-299.

Ontario Ministry of Transportation (2015). Ontario Provincial Highways Traffic Volumes on Demand. Retrieved from http://www.raqsb.mto.gov.on.ca/techpubs/Traffic Volumes.nsf/tvweb?OpenForm\&Seq=1

Roger Brooks International (2015). Devon, Alberta. Retrieved from http://www.rogerbrooksinternational.com/portfolio-items/devon-alberta-bike/

Sorbara, G. (2009, February). Discovering Ontario, a report on the future of tourism. Retrieved from http://www.mtc.gov.on.ca/en/publications/Discover_Ontario_en.pdf

Statistics Canada (2015). Table 1 Annual population estimates by census metropolitan area, July 1, 2014. Retrieved from http://www.statcan.gc.ca/daily-quotidien/150211/t150211a001-eng.htm United Nations (2010). International Recommendations for Tourism Statistics 2008. Retrieved from http://unstats.un.org/unsd/publication/Seriesm/SeriesM_83rev1e.pdf

urbanMetrics (2013). The Downtown Action Plan. Toronto: Author.

York Region (2007). Long Term Tourism Destination Development Strategy - Draft for Consultation. Retrieved from http://archives.york.ca/councilcommitteearchives/pdf/jan\%207\%20long\%20att\%201.pdf 